\title{
Middle manager role and contribution towards the competitive intelligence process: A case of Irish subsidiaries
}

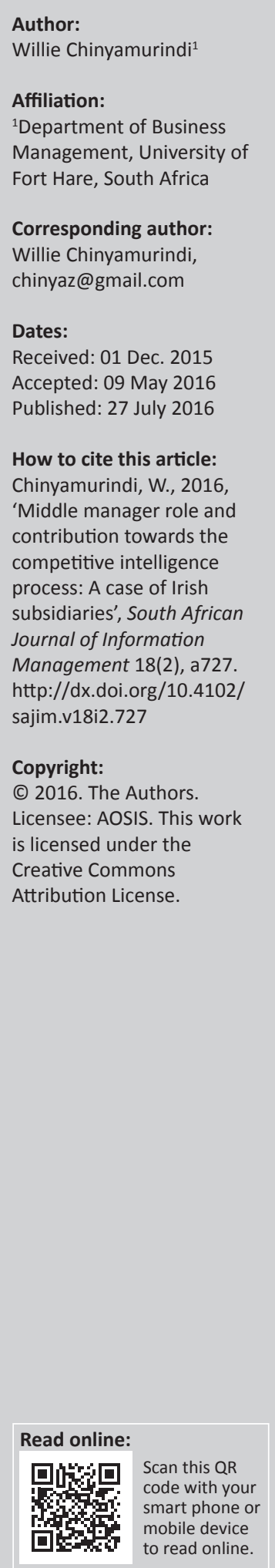

Background: Calls have been made especially during a period of global competition and economic austerity for research that focuses on how competitive intelligence (CI) is actually generated within organisations.

Objectives: The aim of this study was to understand the views and experiences of middle managers with regard to their role and contribution towards the CI process within Irish subsidiaries of the Multinational Corporation (MNC).

Method: The study adopts a qualitative approach using the semi-structured interview technique to generate narratives and themes around how CI is generated using a sample of 15 middle managers drawn from five participating Irish subsidiaries.

Results: Based on the analysis of the narratives of the middle managers, three main themes emerged as findings. Firstly, the process of gathering CI was facilitated by the reliance on internal and external tools. Secondly, information gathered from the use of such tools was then communicated by middle managers to top managers to inform the making of strategic decisions. Thus, (and thirdly), middle managers were found to occupy an important role not only through the execution of their management duties but by extending this influence towards the generation of information deemed to affect the competitive position of not just the subsidiary but also the parent company.

Conclusion: The study concludes by focusing on the implications and recommendations based on the three themes drawn from the empirical data.

\section{Introduction}

The role and contribution of middle managers towards the strategic planning process is receiving empirical attention in multiple contexts (e.g. Rouleau \& Balogun 2011; Salih \& Doll 2013; Teulier \& Rouleau 2013). This study extends this focus by paying attention to the role and contribution of middle managers towards the competitive intelligence (CI) process as a component of how strategy is realised within organisations. There is need to clarify some key concepts that appear constantly in this article.

Firstly, CI is widely discussed in the extant literature. Herring (2007) argues for CI as a strategic tool used to facilitate the identification of potential opportunities and threats. Thus, a useful platform of generating data that determines not only the performance of the organisation's CI (Xu et al. 2011) but also its competitiveness in relation to other players in the same industry (Du Toit \& Sewdass 2014:1). In essence, strategic planning (including efforts towards CI) is a skill for survival and success in an uncertain world (Salih \& Doll 2013), hence the need to pay attention to them. The second key concept in this article is the resource-based view (RBV) of the firm proposed by Barney (1991). The underlying premise with the RBV is the need to strategically position a firm's resources and its interaction with the environment (internal and external) as a basis for attaining competitiveness (Xu et al. 2011).

In essence, CI relies on resources. Some scholars praise the role and existence of human capital within the organisation as important in gathering, organising and utilising information (Xu et al. 2011). This places such human capital as important players within organisations through a resource allocation role (Mariadoss et al. 2014). Resources within an organisation such as employees and managers are key in determining the competitiveness of the firm through the use of tools such as competitor analysis and an analysis of wider industry trends (Opait et al. 2016). Herring (2007:26) 
argues for the importance of CI: 'information costs money, while intelligence makes money. Moreover, intelligence that makes money for a company is valued intelligence'. Resources (the presence and utilisation of them) have a bearing in determining competitiveness.

A general research question was proposed: What are the views and experiences of middle managers with regard to their role and contribution towards the competitive intelligence process within Irish subsidiaries?

In following from previous studies (e.g. Salih \& Doll 2013:32), a broad research question was set to 'elicit a wide range of views and perceptions' around the phenomena understudy. The structure followed in this article is firstly, to put this research into context. Secondly, the theoretical framework underlying this study is presented, leading to the justification of the research question. Thirdly, the research design and methodology section follows. Finally, the results, discussion and a conclusion are presented.

\section{Putting this research into context}

The author of this article was based in Ireland for a period of 2 years when this study was conducted. The context in which this study was conducted was based on Multinational Corporation (MNC), where the subsidiary level was used as the unit of analysis. The MNC can be conceptualised as a collection of globally dispersed units possessing distinctive resources (Noble 1999). Though emphasis is on the distinctive resources, it is worth to mention that subsidiaries by function are not meant to exist in isolation but operating with various corporate units and business actors (Noble, Sinha \& Kumar 2002). Thus, this study is contextualised within the MNC (and subsidiary level) context in understanding aspects of competitiveness and the role of middle managers. The main reason for this has to do with the acknowledgement of the need for subsidiaries as an extension for the MNC to grow. White and Poynter (1984) suggested that this can happen within the subsidiary through: (1) the start-up of sales activities in new geographical markets which is represented by a change in scope, (2) a change in product scope where the subsidiary has to extend a product line (product modifications) or introduce new product areas, and (3) through an extension of basic value chain activities, such as primary activities (inbound logistics, operations, outbound logistics, marketing and sales or service) or support activities like procurement, technological development, human resources management or infrastructure. Thus, through such efforts, a subsidiary is being competitive and yielding benefit not just for its own operation but that of the parent company (Dörrenbächer \& Geppert 2009).

Furthermore, the competitive orientation of a subsidiary can be thought of as encompassing the extent to which the subsidiary not only understands its strengths and weaknesses but also the tactical and strategic capabilities of both current and potential competitors (Noble et al. 2002). Competitive intensity is high when competitor's actions contribute to market uncertainty and customer needs are constantly in flux (Calof \& Wright 2008). The noted challenge for firms is to reduce costs and come to the market quickly and introduce innovative products (Nam et al. 2014). In highly competitive situations, competitive advantage is gained through increased knowledge assets and decreased fixed assets (Barney 1991). Given this, a research question proposed for this study reads: What are the views and experiences of middle managers with regards to their role and contribution towards the competitive intelligence process within Irish subsidiaries?

\section{Theoretical background}

This study considers two main views around aspects on how organisations can be competitive, especially within the MNC. Thus, an eclectic view stemming from previous studies and theorising is preferred. For instance, Amit and Schoemaker (1993) investigated the influences of attaining strategic assets and organisational rent and attributed this to the resources available to the firm, the nature of the industry and managerial decisions. Within the same vein, Birkinshaw (1997) found factors within the subsidiary's local market, internal market (relationships within the MNC) and the global market to be influential towards quests around competitiveness. From this, subsidiaries engage in a process of learning from their environment, thereby allowing them to not only be innovative but also competitive (Saka-Helmhout 2010).

The first consideration gives credence to the presence or absence of resources (physical or human) within the subsidiary as a basis for competitiveness or the lack of it.

In essence, as argued by Barney (1991), it all depends on how resources available to the firm are rare, their ability to be imitated and also how easily such resources can be substituted as a basis for a firm's success and failure. Even though the RBV is a theory of the firm, it is applicable to explain how not only subsidiary strategy but also issues of competitiveness in subsidiaries develop (Birkinshaw 1997). Linked to the RBV is the consideration of management as a driving force of the resources. This becomes the second theoretical consideration; the focus here is on the link between resources and management as influencing not only the development of strategy but also how firms create a competitive advantage in doing so. Thus, another important resource is the role played by management in not only realising strategy but also competitiveness (O'Brien \& Meadows 2013).

\section{Competitive intelligence and management influence}

The management literature identifies a range of sources by which firms can attain a competitive advantage. The emphasis is on the firm's resources as a potential source of attaining a competitive advantage (Barney 1991). However, for these resources to be effectively utilised, other management theorists argue for the need for compatibility or congruence of the organisational components to attain a 
competitive advantage (Argote 1982). The thinking here is that the experience, skills, levels of management and components within the organisation exert a significant effect towards a firm's quest for competitiveness. Given this, efforts towards strategic planning (including CI) are viewed as practice, as something managers use to enact change and also help firms perform (Lechner \& Floyd, 2012).

The concept of competitiveness is one that is receiving attention either at an individual, organisational or country level. The barometer of measuring competitiveness at these three levels is through productivity and effectiveness (Hart \& Spero 1997). One such enabler of an organisation's competitiveness, as argued by Gilad (2011), is the strategic decision-making capability, which is a tool that seeks to generate intelligence and secure a position in spite of changing market conditions. The ultimate aim is to stay ahead of competitors with a thrust towards short- and longterm strategic planning (Dishman \& Pearson 2003). It is envisaged that within organisations, the drivers of efforts towards CI are managers (Nikolaos 2012). CI, thus, emerges as a tool in the hand of managers to be able to not only anticipate environmental change but respond to it (Viviers, Muller \& Du Toit 2005). CI is also a useful tool in the hand of managers to improve decision-making and the attainment of company targets (Du Toit \& Sewdass 2014). Furthermore, Calof and Wright (2008:717) argue for the process of CI not to be an avenue of an elite or the privileged few but to be integrated with the 'knowledge of everyone in the company'.

\section{Middle manager role and contribution}

A middle manager consists of the tier of management between 'the first level supervisor' and upper management who exercise 'company-wide responsibilities' (Herzing \& Jimmieson 2006:628). The main activity base of middle managers, as argued by Floyd and Wooldridge (1994), is to implement those decisions proposed from a higher tier of management above them. In achieving this, middle managers appear to be driven not from the authority above them but the knowledge they have and their ability to be both strategic and operational (Salih \& Doll 2013). Thus, through their activity base, middle managers are involved in CI efforts through their influence towards top managers (Noble 1999). Middle managers are also seekers and implementers of innovations (Bourne \& Walker 2005). Furthermore, Floyd and Lane (2000) argue for middle managers as an important mediator between top managers and those below them. This allows middle managers to expend upwards and downwards influence, especially in strategy formulation and implementation (Wooldridge, Schmid \& Floyd 2008).

A number of scholars make an argument for the importance of middle managers to processes where $\mathrm{CI}$ is generated for organisational decision-making (e.g. Wooldridge et al. 2008; Elbanna 2016; Kealy 2015). Furthermore, calls have been raised in understanding further not only the contribution of middle managers but also their interaction with other actors (such as top managers) within organisations in not only generating $\mathrm{CI}$ but enacting change across the organisation (Balogun 2003; Floyd \& Wooldridge 1994; Raes et al. 2011; Salih \& Doll 2013).

\section{Research methodology}

This study adopted the philosophy of interpretivism which seeks to pave a way in which meaning is interpreted from the lens of the individual (Creswell 2014). Interpretivism is praised as a useful philosophy in understanding complex phenomena and coming to a holistic, rich and in-depth understanding of such phenomena (Creswell 2014). The rationale for this is motivated by the objectives of this study which are exploratory in nature and seeking to gain an understanding of a behaviour (i.e. the views and experiences of middle managers with regard to their role and contribution towards the CI process within Irish subsidiaries) not to predict behaviour (a predominantly positivist stance). Furthermore, the qualitative approach is also adopted and motivated by the need to study 'real people, real problems and real organisations' (Edmondson \& McManus 2007:1155). Such efforts are applauded as they can be forerunners in theory development (Eisenhardt 1989). Within the management sciences, especially the strategy literature, such approaches are receiving attention (Salih \& Doll 2013).

\section{Data collection and analysis}

In achieving the aims of this research, semi-structured interviews were used as a tool for data collection. Interviews help in arriving to an understanding around the depth and complexity of the phenomena under investigation (Creswell 2014). Furthermore, semi-structured interviews boast in allowing for some flexibility in the quality of data that can be collected (Creswell 2014). This can be helpful for the interviewee as they have 'freedom' to express and ascribe meaning to the topic understudy (Noaks \& Wincup 2004:80). A trigger question was asked to initiate the process: 'Can you please tell me a bit about yourself and your role within the MNC?' The duration of each interview was between $1 \mathrm{~h}$ and $1.5 \mathrm{~h}$.

A total of 15 middle managers from five Irish subsidiaries took part in the research (see Table 1). The convenience sampling approach was adopted. The thinking here was to access a sample that is 'available and accessible' to the study (Cohen, Manion \& Morrison 2007). The participants were provided with an outline of the key interview questions in advance of the interview so that they had adequate time for preparation and reflection prior to the interview.

All interviews were conducted at sites where the interviewees deemed as comfortable as it is recommended that interviews of this type take place in a setting natural to the interviewee (Creswell 2014). Given this, participant work sites were used for all interviews. The study paid focus to an inclusion and exclusion standard. Participants had to be middle managers within MNCs in Ireland. Participants were excluded if they did not meet this criterion. 
The interviews were exported into QSR International's NVivo 9, a data analysis and management software package for the purpose of data analysis useful when dealing with a lot of text, graphic, audio and video data (Reuben \& Bobat 2014). A data analysis procedure based on three levels of meaning-making, as adopted in previous research, was used (Chinyamurindi 2012; McCormack 2000).

Level 1 was helpful in developing a good understanding of the contribution and experience of the middle manager to the CI process as per each participant story. This was done by re-reading each interview and listening to audio recordings. This process allowed for the identification of 'markers' in the stories (McCormack 2000:221) and answered questions about each interview, such as 'what kind of story is this?' (Thornhill, Clare \& May 2004:188). Level 2 was achieved through classifying responses from participants into meaningful categories (Nachmias \& Nachmias 1996). Finally, in level 3, the researcher analysed the content of the gathered narrative accounts and themes (McCormack 2000). This was done by identifying themes and using quotes based on consistencies across participant stories (Rhodes 2000). Table 2 presents a summary of the data analysis process.

In ensuring concerns around reliability and validity, some steps were taken. Firstly, ethics approval for the research was granted by the Dublin Institute of Technology in Ireland (where the researcher was based). Furthermore, each company, through their representative, had to give consent before data were collected. Secondly, the interview questions

TABLE 1: Participant characteristics.

\begin{tabular}{|c|c|c|}
\hline Company† & Details of company & $\begin{array}{l}\text { Middle manager position of } \\
\text { participants }\end{array}$ \\
\hline Alphađ & $\begin{array}{l}\text { World leader in manufacturing of } \\
\text { plastic pipe systems with parent } \\
\text { company in the Netherlands. }\end{array}$ & $\begin{array}{l}\text { Strategy } \ddagger \\
\text { Marketing } \ddagger \\
\text { Supply Chain§ }\end{array}$ \\
\hline Betaף & $\begin{array}{l}\text { Global manufacturer and supplier of } \\
\text { medical equipment with parent } \\
\text { company in the United States. }\end{array}$ & $\begin{array}{l}\text { Production }: \\
\text { Supply Chain }\end{array}$ \\
\hline Gammaף & $\begin{array}{l}\text { Airline service company and } \\
\text { specialised aircraft parts } \\
\text { manufacturer with parent company } \\
\text { in Germany. }\end{array}$ & $\begin{array}{l}\text { Marketing } \ddagger \\
\text { Production } \ddagger \\
\text { Supply Chain } \neq \\
\text { Strategy } \$ \\
\text { Quality Assurance }\end{array}$ \\
\hline Deltaף & $\begin{array}{l}\text { Management consulting and } \\
\text { technology services company with } \\
\text { parent company in the United States. }\end{array}$ & $\begin{array}{l}\text { Quality Assurance } \$ \\
\text { Sales \& Marketing } \$ \\
\text { Information Management } \S\end{array}$ \\
\hline Lamda & $\begin{array}{l}\text { Biopharmaceutical company with } \\
\text { parent company in the United Kingdom. }\end{array}$ & $\begin{array}{l}\text { Finance } \S \\
\text { Strategy \& Information } \ddagger\end{array}$ \\
\hline
\end{tabular}

$\dagger, n=15 ;:$, Male participant; $\S$, Female participant; $\uparrow$, Pseudonym.

TABLE 2: Data analysis: Levels of meaning-making.

\begin{tabular}{ll}
\hline Meaning-making & Description \\
\hline Level 1 & $\begin{array}{l}\text { Each interview is written as a brief vignette. Thereafter, each } \\
\text { vignette is then developed into a longer narrative about each } \\
\text { participant. }\end{array}$ \\
Level 2 & $\begin{array}{l}\text { Narrative themes are then conveyed by participants and their } \\
\text { experience of career development. Thereafter, preliminary } \\
\text { themes are then compared across participants. }\end{array}$ \\
Level 3 & $\begin{array}{l}\text { An analysis of the themes from cross-case comparison begins, } \\
\text { and illustrating quotes and stories are used. }\end{array}$ \\
\hline
\end{tabular}

Source: McCormack, C., 2000, 'From interview transcript to interpretative story: Part 1 Viewing the transcript through multiple lenses', Field Methods 12(4), 282-297. http://dx.doi. org/10.1177/1525822X0001200402 were pre-tested using a sample of five managers (nonparticipants) who fitted the same profile as those interviewed in the main part of the research. Thirdly, to ensure credible data, all interview data were recorded and transcribed verbatim within $24 \mathrm{~h}$. Fourthly, the study relied on multiple participants per participating MNCs. Finally, following transcription of data, participants were emailed a copy of the transcription to verify accuracy as per the interview. All these practices are recommended procedures when conducting research, especially qualitative research (Eisenhardt 1989).

\section{Findings}

Based on the narratives of the 15 middle managers, three themes emerged. Firstly, the process of gathering CI was facilitated by the reliance on internal and external tools. Secondly, information gathered from the use of such tools was then communicated by middle managers to top managers to inform the making of strategic decisions. Thus, (and thirdly), middle managers were found to occupy an important role not only through the execution of their management duties but by extending this influence to the generation of information deemed to affect the competitive position of not just the subsidiary but also the parent company.

\section{Generating competitive intelligence}

Middle managers were requested to indicate how CI was generated within the subsidiary. Figure 1 gives a breakdown of the strategy tools and techniques used when generating CI based on the question posed to middle managers specific to the tools and techniques being used within the subsidiary as per the working year.

From Figure 1, three strategic tools and/or techniques stand out in terms of their use by the middle managers in generating CI, namely:

- Strengths, Weaknesses, Opportunities, Threats (SWOT) analysis

- Reliance on an internal knowledge base

- Scenario planning.

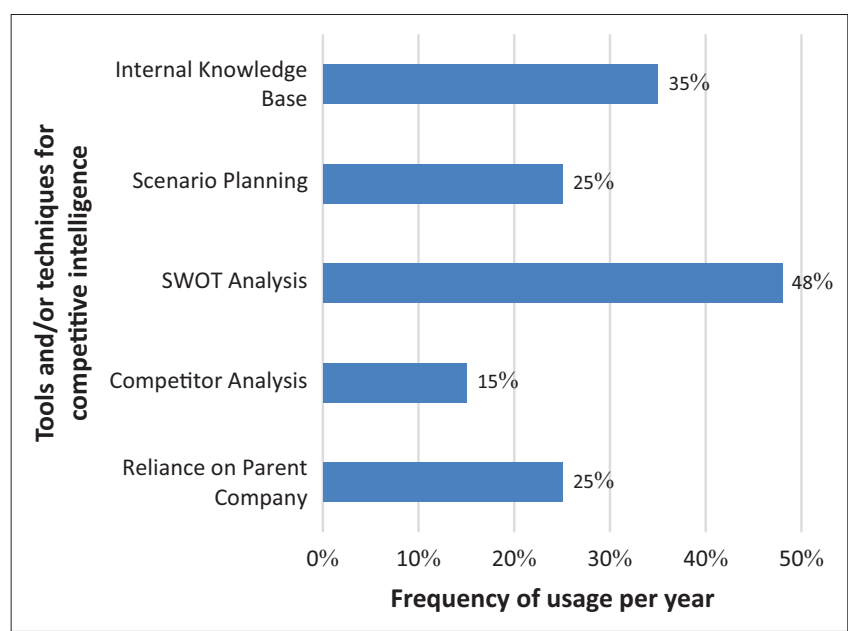

FIGURE 1: Strategic tools and/or techniques used in generating competitive intelligence. 
A sizeable fraction of the middle managers relied on the established techniques used by their parent company to gather data deemed strategic in CI building; next to this, competitor analysis is used by almost a third of the organisations when coming up with strategy. Thus, the data in Figure 1 show that middle managers use and have a wide knowledge of tools and techniques and use these to suit existing business objectives and processes. Further to this, participants were asked to show (if any) the extent to which they use such strategic tools, not just for CI but also for the development of strategy.

Common themes that emerged as to the extent of use of strategic tools for CI were twofold (see Table 3 for illustrating quotes):

- Strategy tools serving as a supportive role to the business objectives and targets of the subsidiary

- Strategy tools serving as a facilitative role towards decision-making.

\section{Middle manager role in competitive intelligence}

A third theme based on the data analysis was around the role of middle managers to the $\mathrm{CI}$ processes. Middle managers

\begin{tabular}{ll}
\begin{tabular}{l} 
TABLE 3: Role of strategy tools and techniques in competitive intelligence. \\
\hline Role of strategy tools and techniques
\end{tabular} & Illustrating quotes \\
\hline $\begin{array}{l}\text { Strategy tools serving as a supportive } \\
\text { role to the business objectives and } \\
\text { targets of the subsidiary. }\end{array}$ & $\begin{array}{l}\text { 'We use SWOT to measure market share } \\
\text { and to respond to our customer needs' } \\
\text { (Beta respondent 1). }\end{array}$ \\
& $\begin{array}{l}\text { 'The SWOT is used to decide on which } \\
\text { manufacturers we can build a relationship } \\
\text { with based upon the elements of the }\end{array}$ \\
$\begin{array}{l}\text { SWOT' (Delta respondent 1). } \\
\text { Strategy tools serving as a facilitative }\end{array}$ & $\begin{array}{l}\text { 'We develop our own methodologies, } \\
\text { role towards decision-making. }\end{array}$ \\
$\begin{array}{l}\text { tools and techniques to guide us through } \\
\text { the process of strategy development' } \\
\text { (Alpha respondent 1). }\end{array}$ \\
$\begin{array}{l}\text { 'We make time to study different } \\
\text { scenarios and select one which best } \\
\text { meets our position and intended action' } \\
\text { (Beta respondent 2). }\end{array}$ \\
\hline
\end{tabular}

were found to occupy an important role not only through the execution of their management duties but by extending this influence to the generation of information deemed to affect the competitive position of not just the subsidiary but also the parent company. Within this, middle managers exercise upwards and downwards influence in supporting CI processes.

Within upwards influence, the middle manager acted and served as a consultant to the top management team by supplying information required in generating information for CI. One middle manager put it simply: 'all I do is supply the parent company with detailed financial packs with information they may use to come up with decisions and this is done on a monthly basis'. (Lamda Respondent). Table 4 shows some quotes on how middle managers exercised upwards influence.

In the second role, the middle manager exerted downwards influence towards strategy development and CI processes. The empirical data shown in Table 4 illustrate that the middle manager in this role acts as the facilitator of the strategy dealing with any perceived obstacles that emerge when pursuing this deliberate strategy. The behaviours reflected in this theme included motivating lower level managers to meet strategic goals and even come up with means through which the subsidiary can compete better. Other behaviours included negotiating with outsiders and channelling employee efforts towards the turn out of the deliberate strategy.

\section{Discussion}

The aim of this study was to understand the views and experiences of middle managers with regard to their role and contribution towards the CI process within Irish subsidiaries of the MNC.

TABLE 4: Middle manager role in competitive intelligence.

\section{Name of company Representative comments}

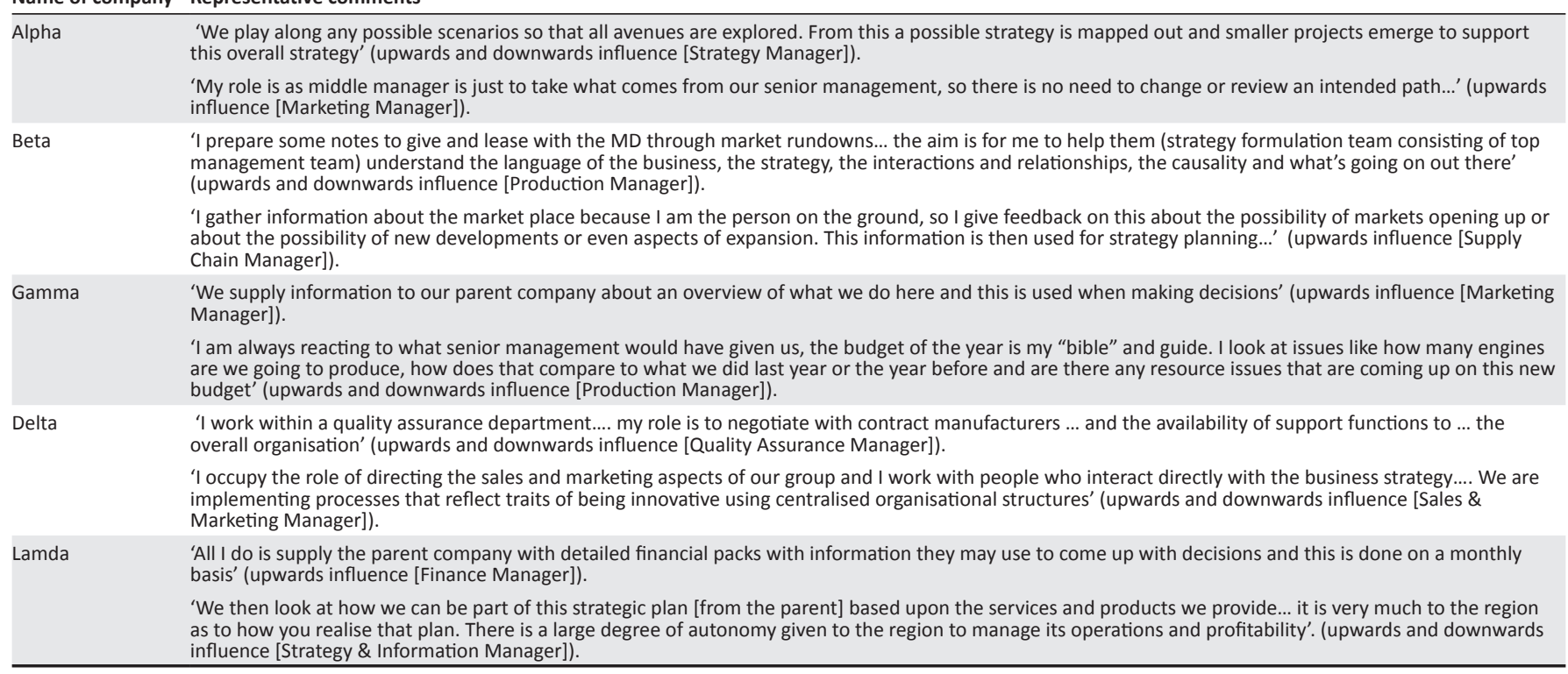




\section{Contributions}

The study valued the role and contribution of middle managers, especially relying on internal and external tools not only as a basis of efforts towards strategy development but also as a capability for attaining a competitive position (O'Brien \& Meadows 2013). In this study, middle managers are illustrated as using these tools as a basis for attaining a competitive position for the subsidiary. In this regard, tools used by subsidiary managers existed also as a way of helping the subsidiary identify its strengths and weaknesses in relation to the competition (Noble et al. 2002) and a basis for innovation (Nam et al. 2014).

The study uniquely illustrates the value that middle managers place on internal sources and tools for gathering information rather than on external sources and tools in generating CI. This could be that internal sources and tools of gathering $\mathrm{CI}$ are more personal and most immediate to middle managers. Thus, internal sources and tools have been illustrated in this study to not only enhancing strategic decision-making (Gilad 2011) but also offering a way for middle managers (and the entire MNC) to understand the local, internal and global markets (Birkinshaw 1997).

For instance, in this study subsidiaries had within them a reference point internally that served as a source of information in generating CI. Such reference points due to their experience were better informed within the subsidiary in introducing not only new products but also product modifications (White \& Poynter 1984). Put differently, information generated internally and externally provides a basis through which the subsidiary learns (Saka-Helmhout 2010) and, by doing so, responds to uncertainty (Viviers et al. 2005). Through such efforts of learning, subsidiaries are not only improving their decision-making capability (Du Toit \& Sewdass 2014) but also positioning themselves as competitive players in an uncertain environment.

Finally, this study extends understanding on the role of middle managers in organisations that has continued (e.g. Balogun 2003; Floyd \& Wooldridge 1994; Raes et al. 2011; Salih \& Doll 2013). The study has not only contributed towards the literature with regard to the strategy development process but also reveals how a middle manager's role and contribution relate with CI generation. In essence, middle managers exist as an important resource (Barney 1991) that can be used to achieve competitiveness for the organisation (Lechner \& Floyd 2012). Thus, this study, through the themes presented, posits middle managers as drivers of the $\mathrm{CI}$ agenda within the MNC subsidiary through their role and contribution to such a process (Nikolaos 2012).

\section{Implications}

The study has a number of implications. Firstly, the study focuses on the strategic importance of middle managers not only in how strategy turns out but also in generating CI. The implication here is that organisations need to be aware of the position of influence that middle managers occupy and their relation with regard to top managers, lower managers and employees. The findings of this study show that middle managers are a bridge between the upper and lower echelons of the organisation, and exert upwards and downwards influence with regard to efforts of being competitive. The results of this study also reinforced the idea of middle managers not only providing information to upper management for strategy formulation but also being actively involved in implementing these strategic outcomes.

The second managerial implication is the influence of the environment on subsidiary management and the process of CI. Subsidiary management needs to constantly monitor and scan their environment to help get the best and accurate information to be used with regard to strategy decisionmaking. To this end, the results of the study highlight the need for organisations to constantly keep an ear on the ground as a basis for remaining competitive.

The third managerial implication, linked to the second one, concerns the tools and techniques for gathering data from the environment to not only make strategic decisions but generate information that makes the subsidiary competitive. Due to the uncertainty in the environment, multiple methods of gathering information are preferred as they help offering a more accurate means of understanding data from the environment. Thus, usage of multiple tools and sources can help unearth new strategic insights and opportunities for subsidiary management and competitiveness.

\section{Limitations}

Some limitations exist with this work. Firstly, the study was interpretive and based on a specific context and has used a specific local example; the problem with this is that it cannot be assumed that the same observable patterns will emerge in the future. This plays well with the fact that only five subsidiaries (15 middle managers) took part in the study and hence the results may not be applicable not only to other subsidiaries but countries as well. Secondly, a small sample size was used for this study. Regardless of these limitations, the study has enhanced understanding in the experience in terms of the role and contribution of middle managers to the process of $\mathrm{CI}$.

Future research could use a larger sample size in an attempt to obtain normative data. Future research may also benefit by improving from the methodology used in this study and incorporate a triangulation approach which could involve a combination of qualitative and quantitative research methods. Future research could also investigate the effects of national culture on CI generation as a basis to account for the role of macro factors not only on the strategy development processes but also for CI. Future research could also provide insight into the applicability of the study's results for samples from similar industries as well as various contexts. It is envisioned that this can help with comparability and enhance an understanding of CI processes within the same industries or different contexts. 


\section{Conclusion}

The compelling theme that emerges from this study is that middle managers are an important conduit in the decisions that determine not only subsidiary performance but the competitiveness of the subsidiary within the MNC. One such way that this has been illustrated to happen through CI. It would appear that through their strategic position within the organisation, middle managers exert an influence towards efforts of CI. Strategic tools and techniques exist as key tools in the generation of data that helps determining the competitiveness of the subsidiary. Notably, the reliance on the tried and trusted sources of data generation such as internal expertise is given priority. This study heightens awareness to the issue that the middle manager is not dead but active. CI generation exists as one such useful activity that gives life to the middle-management tier.

\section{Acknowledgements}

\section{Competing interests}

The author declares that he has no financial or personal relationships which may have inappropriately influenced him in writing this article.

\section{References}

Amit, R. \& Schoemaker, P.J.H., 1993, 'Strategic assets and organisational rent', Strategic Management Journal 14(1), 33-46. http://dx.doi.org/10.1002/smj.4250140105

Argote, L., 1982, 'Input uncertainty and organisational coordination in hospital emergency service units', Administrative Science Quarterly 27, 420-434. emergency service units', Administr
$\mathrm{http} / / / \mathrm{dx}$.doi.org/10.2307/2392320

Balogun, J., 2003, 'From blaming the middle to harnessing its potential: Creating change intermediaries', British Journal of Management 14(1), 69-83. http://dx.doi.org/ intermediaries', British Journa

Barney, J.B. 1991, 'Firm resources and sustained competitive advantage', Journal of Management 17(1), 99-120. http://dx.doi.org/10.1177/014920639101700108

Birkinshaw, J., 1997, 'Entrepreneurship in multinational corporations: The characteristics of subsidiary initiatives', Strategic Management Journal 18(3), 207-229. http://dx.doi.org/10.1002/(SICI)1097-0266(199703)18:3<207::AIDSMJ864>3.0.CO;2-Q

Bourne, L. \& Walker, D.H.T., 2005, 'The paradox of project control', Team Performance Management 11, 157-178. http://dx.doi.org/10.1108/13527590510617747

Calof, J.L. \& Wright, S., 2008, 'Competitive intelligence: A practitioner, academic and inter-disciplinary perspective', European Journal of Marketing 42(7/8), 717-730. $\mathrm{http}: / / \mathrm{dx}$.doi.org/10.1108/03090560810877114

Chinyamurindi, W.T. 2012, 'An investigation of career change using a narrative and story-telling inquiry', South African Journal of Human Resource Management 10(2), 1-11. http://dx.doi.org/10.4102/sajhrm.v10i2.447

Cohen, L., Manion, L. \& Morrison, K., 2007, Research methods in education, 6th edn., Routledge-Falmer, London.

Creswell, J.W., 2014, Research design: Qualitative, quantitative, and mixed methods approaches, 4th edn., Sage, Thousand Oaks, CA

Dishman, P. \& Pearson, T., 2003, 'Assessing intelligence as learning within an industrial marketing group: A pilot study', Industrial Marketing Management 32(7), 615-620. http://dx.doi.org/10.1016/S0019-8501(03)00030-0

Dörrenbächer, C. \& Geppert, M., 2009, 'A micro-political perspective on subsidiary initiative taking: Evidence from German-owned subsidiaries in France', European Management Journal27(2), 100-112. http://dx.doi.org/10.1016/j.emj.2008.06.004

Du Toit, A.S.A. \& Sewdass, N., 2014, 'A comparison of competitive intelligence activities in Brazil, Malaysia, Morocco and South Africa', Acta Commercii 14(1) 1-7. http://dx.doi.org/10.4102/ac.v14i1.234

Edmondson, A.C. \& McManus, S.E., 2007, 'Methodological fit in management field research', Academy of Management Review 32(4), 1155-1179. http://dx.doi. org/10.5465/AMR.2007.26586086

Eisenhardt, K.M. 1989, 'Building theories from case study research', Academy of Management Review 14(4), 532-550.

Elbanna, S. 2016, 'Manager's autonomy, strategic control, organizational politics and strategic planning effectiveness: An empirical investigation into the missing links in the hotel sector', Tourism Management 52, 210-220. http://dx.doi. org/10.1016/j.tourman.2015.06.025
Floyd, S.W. \& Lane, P.J., 2000, 'Strategising throughout the organisation: Managing role conflict in strategic renewal', Academy of Management Review 25, 154-177.

Floyd, S.W. \& Wooldridge, B., 1994, 'Dinosaurs or dynamos? Recognising middle management's strategic role', Academy of Management Executive 8(1), 47-57.

Gilad, B., 2011, 'Strategy without intelligence, intelligence without strategy', Business Strategy Series 12(1), 4-11. http://dx.doi.org/10.1108/17515631111106821

Hart, J. \& Spero, J., 1997, The politics of international economic relations, 5th edn., Bedford/St. Martin's Press, New York.

Herring, J.P., 2007, 'How much is your competitive intelligence worth?', Competitive Intelligence Magazine 10(2), 23-26.

Herzing, S.E. \& Jimmieson N.L., 2006, 'Middle managers' uncertainty management during organisational change', Leadership \& Organisation Development Journal 27(8), 628-645. http://dx.doi.org/10.1108/01437730610709264

Kealy, T., 2015, 'Do middle managers contribute to their organisation's strategy?', International Journal of Humanities and Social Science 5(1), 108-116.

Lechner, C. \& Floyd, S.W., 2012, 'Group influence activities and the performance of strategic initiatives', Strategic Management Journal 33, 478-495. http://dx.doi. org/10.1002/smj.959

Mariadoss, B.J., Milewicz, C., Lee, S. \& Sahaym, A., 2014, 'Sales person competitive intelligence \& performance: The role of product knowledge and sales force automation usage', Industrial Marketing Management 43, 136-145. http://dx.doi. org/10.1016/j.indmarman.2013.08.005

McCormack, C., 2000, 'From interview transcript to interpretative story: Part 1. Viewing the transcript through multiple lenses', Field Methods 12(4), 282-297. $\mathrm{http}: / / \mathrm{dx}$.doi.org/10.1177/1525822X0001200402

Nam, D., Parboteeah, K.P., Cullen, J.B. \& Johnson, J.L., 2014, 'Cross-national differences in firms undertaking innovation initiatives: An application of institutional anomie in firms undertaking innovation initiatives: An application of institutional anomie
theory', Journal of International Management 20,91-106. http://dx.doi. org/10.1016/j.intman.2013.05.001

Nachmias, F.C. \& Nachmias, D., 1996, Research methods in the social sciences, 5th edn., Worth Publishers, New York.

Nikolaos, T., 2012, 'Competitive intelligence: Concept, context and a case of its application', Science Journal of Business Management 2, 1-15.

Noaks, L. \& Wincup, E., 2004, Criminological research: Understanding qualitative methods, Sage, London.

Noble, C.H., 1999, 'The eclectic roots of strategy implementation research', Journal of Business Research 45, 119-134. http://dx.doi.org/10.1016/S0148-2963(97)00231-2

Noble, C.H., Sinha, R.K. \& Kumar, A., 2002, 'Market orientation and alternative strategic orientations: A longitudinal assessment of performance implications', Journal of Marketing 66(4), 25-40. http://dx.doi.org/10.1509/jmkg.66.4.25.18513

O'Brien, F. \& Meadows, M., 2013, 'Scenario orientation and use to support strategy development', Technological Forecasting and Social Change 80(4), 643-656. http://dx.doi.org/10.1016/j.techfore.2012.06.006

Opait, G., Bleoju, G., Nistor, R. \& Capatina, A., 2016, 'The influences of competitive intelligence budgets on information energy dynamics', Journal of Business Review $69,1682-1689$.

Raes, A.M., Heijltjes, M.G., Glunk, U. \& Roe, R.A., 2011, 'The interface of the top management team and middle managers: A process model', Academy of Management Review 36(1), 102-126. http://dx.doi.org/10.5465/amr.2009.0088

Reuben, S. \& Bobat, S., 2014, 'Constructing racial hierarchies of skill-experiencing affirmative action in a South African organisation: A qualitative review', South African Journal of Industrial Psychology 40(1), 1-12. http://dx.doi.org/ 10.4102/sajip.v40i1.1158

Rhodes, H., 2000, 'Mid-life career change to home-based self-employment in a group of women', Master's thesis, Department of Sociology, Simon Fraser University.

Rouleau, L. \& Balogun, J., 2011, 'Middle managers, strategic sense-making, and discursive competence', Journal of Management Studies 48(5), 953-983. http:// discursive competence', Journal of Management
dx.doi.org/10.1111/j.1467-6486.2010.00941.x

Saka-Helmhout, A., 2010, 'Organisational learning as a situated routine-based activity in international settings', Journal of World Business 45, 41-48. http://dx.doi. org/10.1016/j.jwb.2009.04.009

Salih, A. \& Doll, Y., 2013, 'A middle management perspective on strategy implementation', International Journal of Business and Management 8(22), 32-39. http://dx.doi.org/10.5539/ijbm.v8n22p32

Teulier, R. \& Rouleau, L., 2013, 'Middle managers' sense-making and interorganisational change initiation: Translation spaces and editing practices', Journal of Change Management 13(3), 308-337. http://dx.doi.org/10.1080/14697017.2013.822674

Thornhill, H., Clare, L. \& May, R., 2004, 'Escape, enlightenment and endurance: Narratives of recovery from psychosis', Anthropology and Medicine 11, 181-199. http://dx.doi.org/10.1080/13648470410001678677

Viviers, W., Muller, M.L. \& Du Toit, A.S.A., 2005, 'Competitive intelligence: An instrument to enhance competitiveness in South Africa', South African Journal of Economic and Management Sciences 8(2), 246-254.

White, R.E. \& Poynter, T.A., 1984, 'Strategies for foreign-owned subsidiaries in Canada', Business Quarterly Summer, 59-69.

Wooldridge, B., Schmidt, T. \& Floyd, S., 2008, 'The middle management perspective on strategy process: Contributions, synthesis, and future research', Journal of Management 34(6), 1190-1221. http://dx.doi.org/10.1177/0149206308324326

Xu, K., Liao, S.S., Li, J. \& Song, Y., 2011, 'Mining comparative opinions from customer reviews for competitive intelligence', Decision Support System 50, 743-754. http://dx.doi.org/10.1016/j.dss.2010.08.021 